\title{
POTENTIAL OF SOME MEDICINAL AND FODDER CROPS TO ALLEVIATE SOIL SICKNESS IN THE OLD PRUNUS PERSICA VAR. PERSICA (L.) BATSCH AND MALUS DOMESTICA BORKH. TREE MONOCULTURES
}

\section{Didyk Nataliya*, Ivanytska Bogdana}

M.M.Gryshko National Botanical Garden of the National Academy of Sciences of Ukraine, Department of Allelopathy, Kyiv, Ukraine

Received: 9. 2. 2020 Revised: 15. 4.2020 Published: 20. 11. 2020

The effect of nine species of cover crops (calendula, eastern galega, tartary buckwheat, mustard, tansy phacelia, lemon balm, golden marigold, sainfoin, blue fenugreek) on allelopathic and biochemical characteristics of the rhizosphere soil from-under 30-year-old Malus domestica Borkh. and Prunus persica var. persica (L.) Batsch plantations in model laboratory experiments were studied. The samples of the rhizosphere soil were collected at the beginning of the growing season (fruit trees bud development), dried, sieved and placed into the plastic pots. The seeds of the tested cover crops were sown into the pots. After the emergence of the seedlings 10 plants per pot were left and cultivated for 4 months under laboratory conditions. The contents of the nutrients, organic carbon and soil acidity were determined at the beginning of the experiments. Every two weeks after the start of the experiments, the allelopathic activity of the soil was assessed using bioassays on the cress root growth and radish seeds germination. The number of free phenolics in soil solution was determined at the beginning and the end of the experiments. Analysis of the content of soil nutrients showed that the content of manganese and iron 3-6-fold exceeded the optimum level, and the content of free phenolics in soil solution exceeded the phytotoxic threshold almost 10 -fold. Growing of cover crops improved the allelopathic and biochemical regime of the studied soil. The most effective were Tagetes tenuifolia, Phacelia tanacetifolia, and Sinapis alba. The size of the positive effect was correlated with the duration of cultivation of the cover crops in the soil. We consider the above-mentioned plant species promising for further study of their potential to restore soil fertility in the old apple and peach orchards.

Keywords: cover crops, soil sickness, old monoculture, apple tree, peach tree

\section{Introduction}

Presently soil sickness (SS), which is also known in agronomy as "soil fatigue" or "replant disease problem", in the orchards of fruit trees is a global problem, causing huge economic losses for fruit producers and significantly limiting the development of fruit production

*Corresponding author: Nataliya Didyk, Str. Timiryazyevska 1, 01014, Kyiv, Ukraine $\triangle$ nataliya_didyk@ukr.net 
(Benizri et al., 2005; Lü et al., 2018). SS affects most of the fruit trees including both pome and stone fruit trees after long-term (commonly 20 -ty years and more) cultivation of the same orchard species in the same field. As a result, a general decline in the growth and productivity, vigor and performance of the fruit trees are observed, without causes clearly defined (Benizri et al., 2005; Thakur et al., 2018).

Plant ecologists refer to SS as a negative plant-soil feedback emphasizing the mutual negative interactions between plant and soil (Cesarano et al., 2017). The problem is specific to a plant genus or species and persists for up to 20 to 30 years. The problem of SS in the fruit orchards was reported in the literature for more than two centuries ago. However, until the present, the causes of this phenomenon have not been clearly defined yet. The decline in the fruit yield has been attributed to phytotoxic allelochemicals, depletion of mineral nutrients, phytopathogenic fungi, bacteria, insects, and nematodes (Benizri et al., 2005). However, none of the mentioned above factors fully explain the species-specificity, as well as the long durability of SS. A better understanding of the factors causing SS is a necessary step to develop eco-friendly solutions to overcome this problem.

Analysis of the available literature data on SS in apple and peach orchards revealed that one of the underlying causative mechanisms of this problem is the accumulation of phytotoxic phenolics in the rhizosphere soil. Particularly, phlorizin, phenolic acids, vanillic aldehyde, etc. were found to be responsible for SS in old apple monoculture. While in the rhizosphere soil from under old peach tree phytotoxic concentrations of catechin, amygdalin, and their derivatives were reported (Moroz, 1990; Liu et al., 2008; Yin et al., 2016). The mentioned above allelopathic inhibitors showed phytotoxic effects on a wide range of higher plants (Reigosa and Pazos-Malvido, 2007; Yin et al., 2016). It has also been shown that the decay products of root and leaf residues of apple and peach trees stimulate the development of phytopathogenic and producing phytotoxic substances microorganisms and inhibit agronomically beneficial microflora (Čatská et al., 1982; Benizri et al., 2005). Particularly, in the rhizosphere soil of older apple trees, an increase in the counts of micromycetes and actinomycetes and a decrease in bacterial counts were found in agreement with the decreasing $\mathrm{pH}$ of the rhizosphere soil. The number of phytotoxic micromycetes was higher in 'sick' soil as compared with control soil in which apple trees had not been grown for at least 15 years. The latter, via their metabolites, affected negatively the microbial equilibrium and biological activity of the soil and thus also the growth, development, and health of the plants (Čatská et al., 1982). Benizri et al. (2005) noted a shift in the structure of bacterial communities in "sick" peach tree rhizosphere soil with an increase in phytotoxic microorganisms capable of producing toxic cyanide compounds and inhibition of beneficial microbiota. The inhibition of the growth of agronomically useful microflora leads to enhanced development of soil-borne pathogenic microbiota (Manici et al., 2003). The mentioned changes in soil biochemical and biological characteristics impair soil structure and cause depletion or immobilization of nutrients which, in turn, worsen further growth condition for cultivated plants (Moroz, 1990; Politycka and Adamska, 2003).

In this context, chemical or/and biological removal of phytotoxins is of utmost importance because it affects not only plant vigor and growth, but also the structure and performance of soil microbiota. Present agricultural practices aimed to combat or reduce SS in old apple 
and peach tree orchards include soil fumigation with EDTA (ethylenediaminetetraacetic acid), fertilization, soil chemical sterilization, biocontrol using plants with high phytosanitary potential, arbuscular mycorrhiza and other microbial agents (Moroz, 1990; Singh et al., 2017; Lü et al., 2018; Thakur et al., 2018). Sufficient research has been done on chemical control with fumigation, however, research is needed to develop environment-friendly biological methods and to restore soil fertility (Singh et al., 2017; Thakur et al., 2018). There is also a need to develop an integrated approach combining chemical and biological control of factors causing SS (Singh et al., 2017; Thakur et al., 2018).

In this aspect, the use of cover crops with phytosanitary potential could be a promising solution to the problem of SS in fruit orchards. Cover cropping is environmentally friendly, cost-effective and is less vulnerable to weather fluctuation than microbial preparations. Today cover cropping is widely used to manage soil fertility, water retention capacity, chemical, and physical characteristics, for control of weeds, pests, diseases, as well as an increase in biodiversity and stability of agroecosystems. It is a major challenge in the sustainable management of fruit orchards, because of its complex effect on soil biological, biochemical, agrochemical and physical characteristics. When properly fit cover crops not only alter allelopathic and biochemical regime of the "sick" soil but also enrich the soil with additional organic matter, which stimulates microorganisms involved in mineralization processes and suppresses phytopathogenic and phytotoxic strains (Manici et al., 2015; Zhou et al., 2019). The changes in soil microbial community affect further detoxification and mineralization processes and contribute to the restoration of the balance of nutrients. Besides, their phytomass after incorporation into the soil creates additional moisture reserves (Rodrigues et al., 2018).

In the long-term field studies performed by Moroz (1990) the positive results of cultivation of legumes and cruciferous cover crops in old peach and apple tree orchards for the alleviation of SS were obtained. The best effect was achieved when in the spring under cover of cereals clover or alfalfa were sown and cultivated for 2 years. The described intercropping practice promoted the accumulation of organic matter in the soil, activated microbiological processes and improved allelopathic regime (Moroz, 1990).

The positive effect of the permanent cover of alfalfa plus fescue mixture (Medicago sativa + Festuca arundinacea Schribn.); strawberry clover (Trifolium fragiferum L.), common vetch (Vicia sativa L.) on the mineral nutrients balance in the soil, apple tree growth and yield as compared to control (apple trees are grown with natural vegetation of grasses and legumes) was shown by Sánchez et al. (2007).

Conducted by Alicia Morugán-Coronado et al. (2020) meta-analysis to assess the effect of soil management techniques on soil properties and crop yields in fruit crops (including peach, almond, avocado, citrus, grapevine, etc.) in Mediterranean region highlighted the overall positive effects of permanent intercropping (namely, maintenance of a permanent cover crop in the alleys, such as aromatics Thymus sp, Lavandula sp, Salvia sp, Rosmarinus sp, Brachypodium sp, Asparagus sp or natural grass), and annual intercropping (cover crops in the alleys that are annually harvested or incorporated into the soil) on soil organic 
matter and nitrogen content. The mentioned agricultural practices make the agroecosystem more resilient to drought and erosion events, with no negative effects on fruit yield. The authors concluded that the incorporation of such cropping systems and practices in policy measures could provide a meaningful contribution to securing the long-term soil quality of Mediterranean orchards. The analysis used the results of 187 experimental treatments from 46 peer-reviewed articles, including the countries of Spain, Italy, France, Portugal, Greece, Turkey, Slovenia, Tunisia, Chile and the United States of America.

The impact of three cover crops with phytosanitary potential (namely, barley (Hordeum vulgare L. cv. Tidone), alfalfa (Medicago sativa L. cv. Europe), marigold (Tagetes patula L. cv. Disco Marinetta) on the soil microbial community colonizing apple trees in orchards suffering SS was studied by Manici et al. (2015). All studied cover crops showed the potential to increase soil microbial diversity in long-term permanent cropping systems and to manipulate root colonizing fungi involved in crop health. The most effective in this respect was marigold, which increased the abundance of nonpathogenic root inhabiting fungi and stimulated the growth of young apple seedlings more than other cover crops. The author concludes that the appropriate use of a cover crop pre-plant can reduce the inoculum of soil-borne pathogens and give an effective advantage in the early post-plant stage, during which young fruit trees are most susceptible to root rot fungal pathogens (Manici et al., 2015). Tongy Zhou et al. (2019) demonstrated that the incorporation of cover crops (mixed herbs or red clover) into the soil in apple orchards improved the chemical composition and had a positive influence on microbial communities.

The objective of our study was to evaluate the potential of nine medicinal and fodder crops to alleviate soil sickness in the 30-year-old peach and apple tree monocultures.

\section{Materiall and methodology}

\section{Soil sampling}

Soil samples (gray podzol) for this study were taken at a depth of between 20 and $50 \mathrm{~cm}$ from under 30-year-old apple trees (Malus domestica Borkh., cv. Slava Pobediteliam) and peach trees (Prunus persica var. persica (L.) Batsch, cv. Druzhba) at the beginning of the growing season (bud development stage) cultivated in a fruit orchard at the M.M. Gryshko National Botanical Garden (Kyiv, Ukraine).

\section{Experimental set-up}

Pot experiments were conducted in the laboratory conditions at the Department of Allelopathy of the M.M. Gryshko National Botanical Garden. Air-dried and 2-mm sieved soil was placed into the $1 \mathrm{l}$ plastic pots. The latter were arranged in a randomized block design and maintained at $22-28{ }^{\circ} \mathrm{C}$ with a $12 / 12$ light cycle, soil moisture of $60 \%$ of full physical soil water capacity for 4 mo.

Seeds of calendula (Calendula officinalis L.), eastern galega (Galega orientalis L.), tartary buckwheat (Fagopyrum tataricum L.), mustard (Sinapis alba L.), tansy phacelia (Phacelia tanacetifolia Benth.), lemon balm (Melissa officinalis L.), golden marigold (Tagetes tenuifolia 
Cav.), sainfoin (Onobrychis arenaria (Kit.) DC.), blue fenugreek (Trigonella caerulea (L.) Ser.) were surface-sterilized with $1 \%$ sodium hypochlorite and sown into the pots. After the emergence of seedlings, they were thinned to 10 plants per pot.

\section{Assessment of soil characteristics}

The amounts of nutrients, organic carbon, and soil acidity were determined at the beginning of the experiments. The content of biogenic elements in soil samples was analyzed using the method described by G. Ya. Rinkis and V.F. Nollendorf(1982) with the help of spectrophotometer ICAP 6300 DUO. The acidity of soil solution was determined using ion meter HI 2211 (HANNA Instruments).

Every two weeks after the start of the experiment, the allelopathic activity of the soil was determined using bioassays on cress (Lepidium sativum L.) radicle elongation and radish (Raphanus sativus L., cv. Krasny s belym konchikom) seeds germination (Grodzinski, 1991). As a control, we used the same fruit tree rhizosphere soil exposed to the same temperature, light and watering conditions but without cover crops. Seeds of the test plants were surface-sterilized with $1 \%$ sodium hypochlorite. For germination tests and root elongation tests, seeds were sown on Whatman no.1 paper disks placed over the tested soil samples in Petri dishes with 10-cm-diam. All control and test treatments were replicated three times. Germination was assessed after 48 hours; radicle length was measured 3 days after cress seeds were sown.

The content of free phenolics in the soil solution was determined at the beginning and the end of the experiments. Phenolic allelochemicals were extracted from soil samples with methanol and their amount was determined by the method described in (Grodzinski et al., 1988) with the help of spectrophotometer Specord 200, Analytic Yena 2003.

\section{Statistic analysis}

Statistical analysis on quantitative data and visualization of the results was performed using descriptive statistics and ANOVA with the help of STATISTICA 10.0 software (StatSoft Inc., Tulsa, Oklahoma, USA) and Microsoft Excel 7.0. Mean germination and mean root elongation indices were compared to their respective controls. The results of the assessment of the allelopathic activity of soil samples presented on figures are \% to their respective values in control. The least significant differences test (LSD at $p<0.01$ ) was used to compare the means of different treatments.

\section{Results and discussion}

Analysis of the nutrients contained in the soil collected from under 30-year-old apple and peach trees showed that the content of manganese under the apple trees was within $179.4 \mathrm{mg} / \mathrm{l}$ of soil. This is $20 \%$ above the phytotoxicity threshold of this metal in soil solution (150 mg/l of soil) according to (Bityutskiy, 2014). Iron content in soil under peach $375 \mathrm{mg} / \mathrm{l}$ by $25 \%$ exceeded the phytotoxicity threshold of this element in soil solution $(300 \mathrm{mg} / \mathrm{l} \mathrm{soil}$, according to Bityutskiy (2014) (Table 1). 
Table 1 The content of mineral nutrients (mg/l of soil), hummus (C\%), free phenolics (mg/l of soil), $\mathrm{pH}$ in soil from under 30-year-old apple and peach trees plantations, $p<0.01$

\begin{tabular}{lcccccccccccc}
\hline $\begin{array}{l}\text { Fruit } \\
\text { tree }\end{array}$ & $\mathbf{N H}_{4}^{+}$ & $\mathbf{N O}_{3}^{-}$ & $\mathbf{P}$ & $\mathbf{K}$ & $\mathbf{C a}$ & $\mathbf{M g}$ & $\mathbf{F e}$ & $\mathbf{S}$ & $\mathbf{M n}$ & $\mathbf{p H}$ & $\mathbf{C} \%$ & $\begin{array}{c}\text { Total } \\
\text { phenolics }\end{array}$ \\
\hline $\begin{array}{l}\text { Apple } \\
\text { tree }\end{array}$ & 194.7 & 7.5 & 163.5 & 382.5 & $5,831.0$ & 518.2 & 258.5 & 77.4 & 179.4 & 7.21 & 2.05 & 120 \\
$\begin{array}{l}\text { Peach } \\
\text { tree }\end{array}$ & 31.7 & 3.8 & 172.4 & 447.0 & $2,165.0$ & 263.8 & 375.0 & 49.2 & 115.6 & 6.9 & 2.96 & 140 \\
\hline
\end{tabular}

Note: C\% - hummus \%

The content of phenolic allelochemicals in the tested soil samples was 120 and $140 \mathrm{mg}$ per liter, which is almost an order of magnitude higher than the phytotoxicity threshold of these substances - 15-20 mg/l (Reigosa and Pazos-Malvido, 2007; Perveen et al., 2019). Phenolic compounds are a major group of allelochemicals ranging from phenols, hydroxy acids, aldehydes, benzoic acids cinnamic acids, coumarins, tannins, and flavonoids. They are produced by various plant species and their inhibitory effects on higher plants have been well reported (Makoi and Ndakidemi, 2007; Reigosa and Pazos-Malvido, 2007; Liu et al., 2008; Yin et al., 2016). Apparently, the phytotoxicity of the studied soil samples is mainly due to the accumulation of free phenolic compounds. Taking into account the ability of phenolics to form chelate complexes with metals (Makoi and Ndakidemi, 2007), and thus retaining them in the soil medium, it is possible to predict that the toxic effect of the excess concentrations of manganese and iron was also significant.

The results of the allelopathic analysis showed that Ph. tanacetifolia and T. tenuifolia most effectively improved soil allelopathic regime in apple orchards as compared to the other studied cover crops (Figure 1). A significant stimulating effect was observed after a month of cultivation of these cover crops and lasted until the end of the experiments. Somewhat less effective was Trigonella caerulea. Cress radicle elongation was the most responsive to the tested cover crops allelochemicals as compared to radish seed germination. The former bioassay is considered to be one of the most sensitive to phenolic allelochemicals (Perveen et al., 2019).

The results of the allelopathic analysis were in good agreement with the data of the assessment of free phenolics content in the soil solution (Figure 2). The lowest amount of phenolics was revealed after the cultivation of $T$. tenuifolia. A slightly higher content was detected after the cultivation of S. alba, C. officinalis, T. caerulea and Ph. tanacetifolia. The highest amount of phenolics was found after the cultivation of $O$. arenaria.

Similar results were obtained for soil samples collected from under 30-year-old peach trees. All studied cover crops significantly improved the allelopathic and biochemical regimes of this soil (Figure 3 and 4). The greatest positive effect was observed at 3-4 months of cultivation Ph. tanacetifolia and S. alba. 


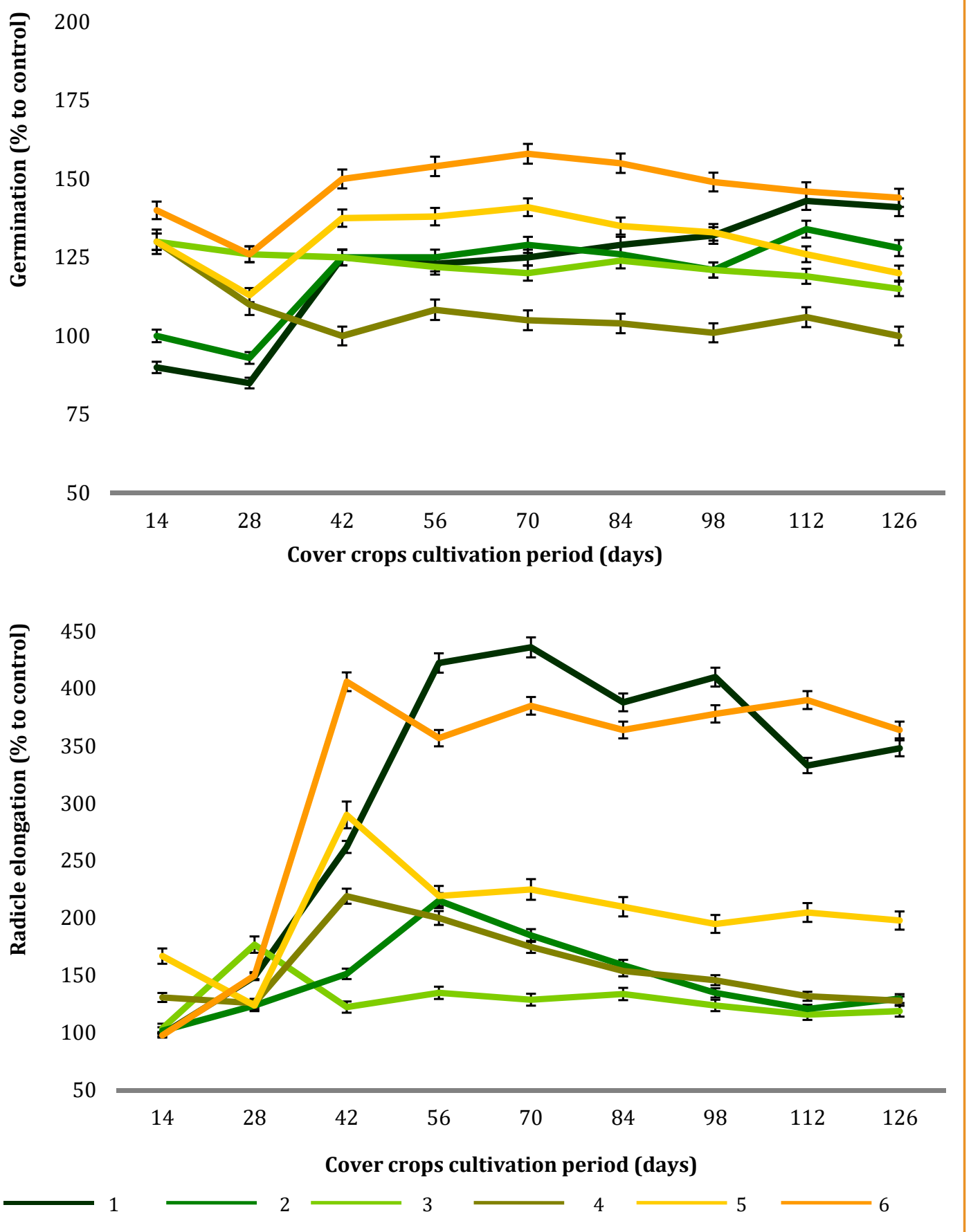

Figure 1 Effect of cover crops cultivation on the allelopathic activity of the soil from-under 30-year-old apple trees. Bioassays: radish seed germination and cress radicle elongation 1 - Tagetes tenuifolia; 2 - Onobrychis arenaria; 3 - Sinapis alba; 4 - Calendula officinalis; 5 - Trigonella caerulea; 6 - Phacelia tanacetifolia. Vertical bars - the least significant difference at $p<0.01 \%$ 


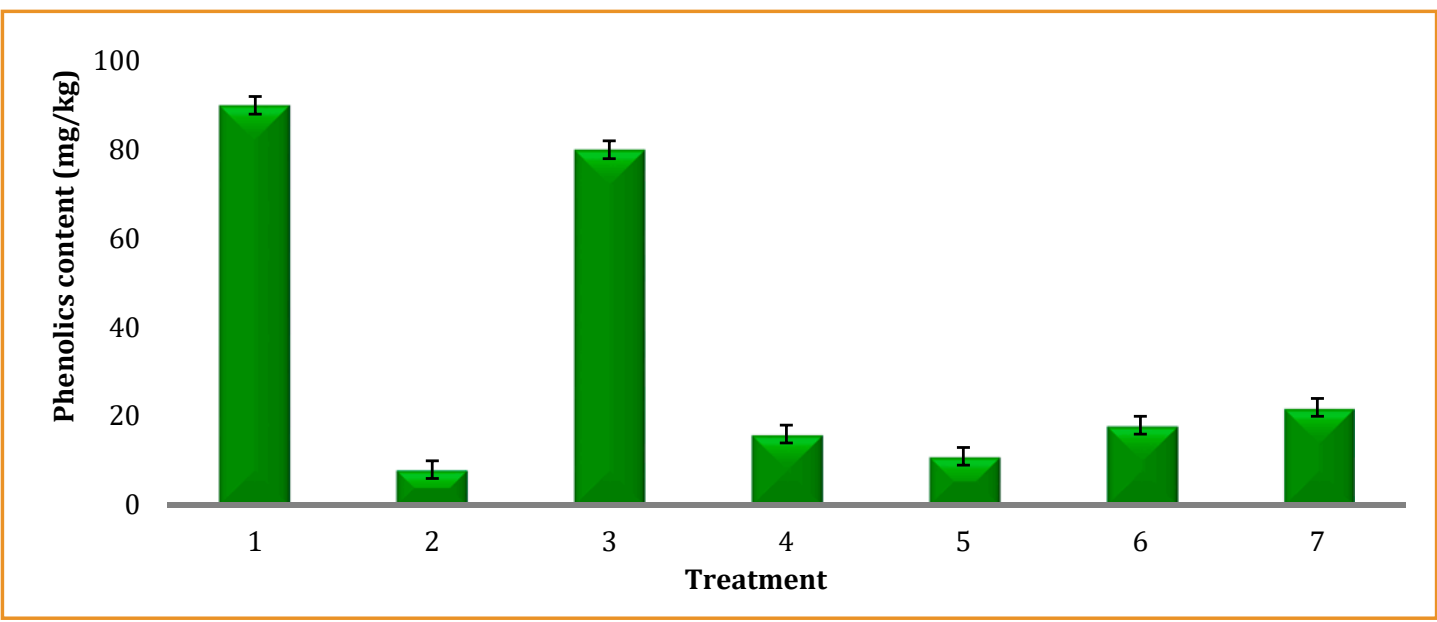

Figure 2 Effect of cover crops cultivation on the content of free phenolics in the soil from-under 30-yearold apple trees after 126 days of cultivation of cover crops

1 - control (without crops); 2 - Tagetes tenuifolia; 3 - Onobrychis arenaria; 4 - Sinapis alba; 5 - Calendula officinalis; 6 - Trigonella caerulea; 7 - Phacelia tanacetifolia. Vertical bars - the least significant difference at $p<0.01$

It should also be noted that all the cover crops studied except Galega orientalis and Onobrychis arenaria significantly reduced the content of free phenolics in soil solution. This not only helped to reduce the phytotoxic properties of the soil but also contributed to the diversity of soil microbiota, including agronomically useful microorganisms. In addition, the observed decrease in the amount of total phenolics increases the mobility of toxic metals such as manganese and iron, facilitating their washing out of the soil solution.

A positive effect of marigold species on the allelopathic and biochemical characteristics of soil was shown in our previous studies (Didyk and Mashkovska, 2006). According to the results obtained by Manici et al. (2015) marigold used as a pre-plant in apple orchards demonstrated the highest stimulative effect on apple rootstock plantlets growth as well as the increase in the abundance of nonpathogenic root inhabiting fungi more compared to the other tested cover crops. Besides, marigolds (Tagetes spp.) have been shown to suppress certain nematode species (Kimpinski et al., 2000) and some noxious weeds (Didyk and Mashkovska, 2006). Tansy phacelia is commonly used as a cover crop in arable rotations and is considered to be particularly effective in conditioning soil structure, in sandy loam and clay soil (Bacq-Labreuil et al., 2019). Root exudations of tansy phacelia were also shown to control root-lesion nematodes (Kimpinski et al., 2000), and the infection by such soil-borne fungi as Alternaria alternata, Fusarium oxysporum, F. culmorum etc. (Patkowska and Konopiński, 2011). Mustard exometabolites contain glucosinolates which could be further hydrolyzed by the enzyme myrosinase to form isothiocyanates (ITCs), compounds toxic to a variety of soil-borne plant pests, including nematodes, bacteria, fungi, and weeds (Matthiessen and Kirkegaard, 2006; Hossain et al., 2015; Brennan and Smith, 2018). Another reason for this suppressive effect could be a change in the structure of the soil microflora (Hossain et al., 2015). Allelochemicals of $S$. alba were shown to selectively inhibit soil-borne pathogens without major side effects 
Didyk, N., Ivanytska, B.

Agr.bio.div. Impr. Nut., Health Life Qual., 2020, 1-12

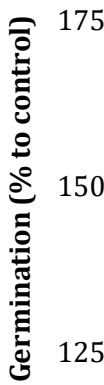

100

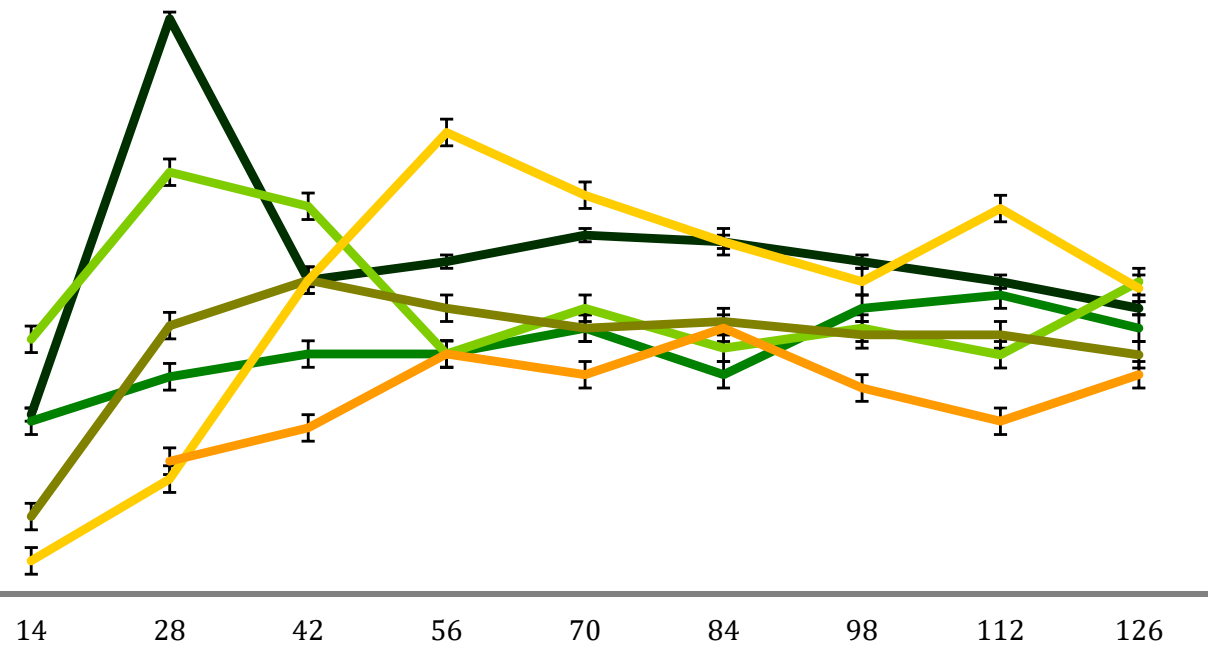

Cover crops cultivation period (days)

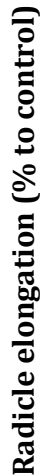

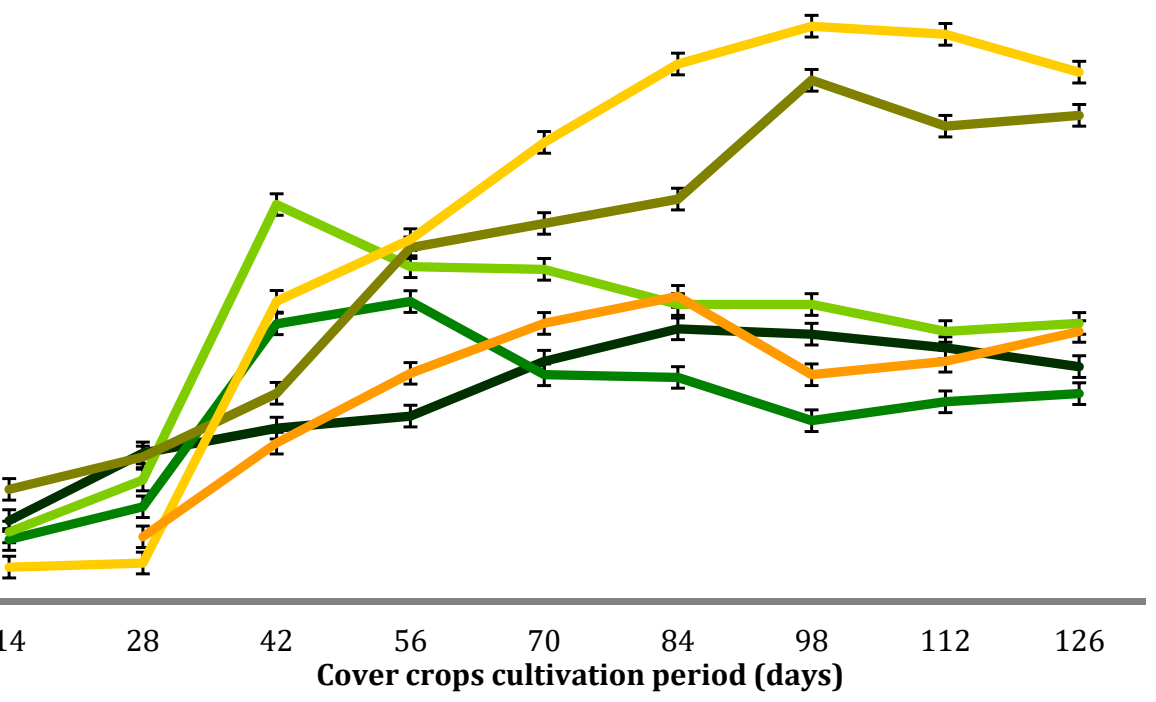

75

Figure 3 Effect of cover crops cultivation on the allelopathic activity of the soil from-under 30-year-old peach trees. Bioassays: radish seed germination and cress radicle elongation

1 - Calendula officinalis; 2 - Galega orientalis; 3 - Fagopyrum tataricum; 4 - Sinapis alba; 5 - Phacelia tanacetifolia; 6 - Melissa officinalis. Vertical bars - the least significant difference at $p<0.01$ 
on the genetic potential of beneficial soil microorganisms involved in $\mathrm{N}$ cycling (Hossain et al., 2015). Besides they stimulate the development of antagonistic organisms towards pathogenic fungi in soil (Matthiessen and Kirkegaard, 2006). The present study demonstrated the good potential of the mentioned above cover crop species to reduce soil phytotoxicity caused by an accumulation of phenolic allelochemicals in old apple and peach tree monocultures. Due to the mentioned above features marigolds, tansy phacelia, and mustard present the most promise for further studies of their effectiveness in alleviating soil sickness in the old fruit orchards.

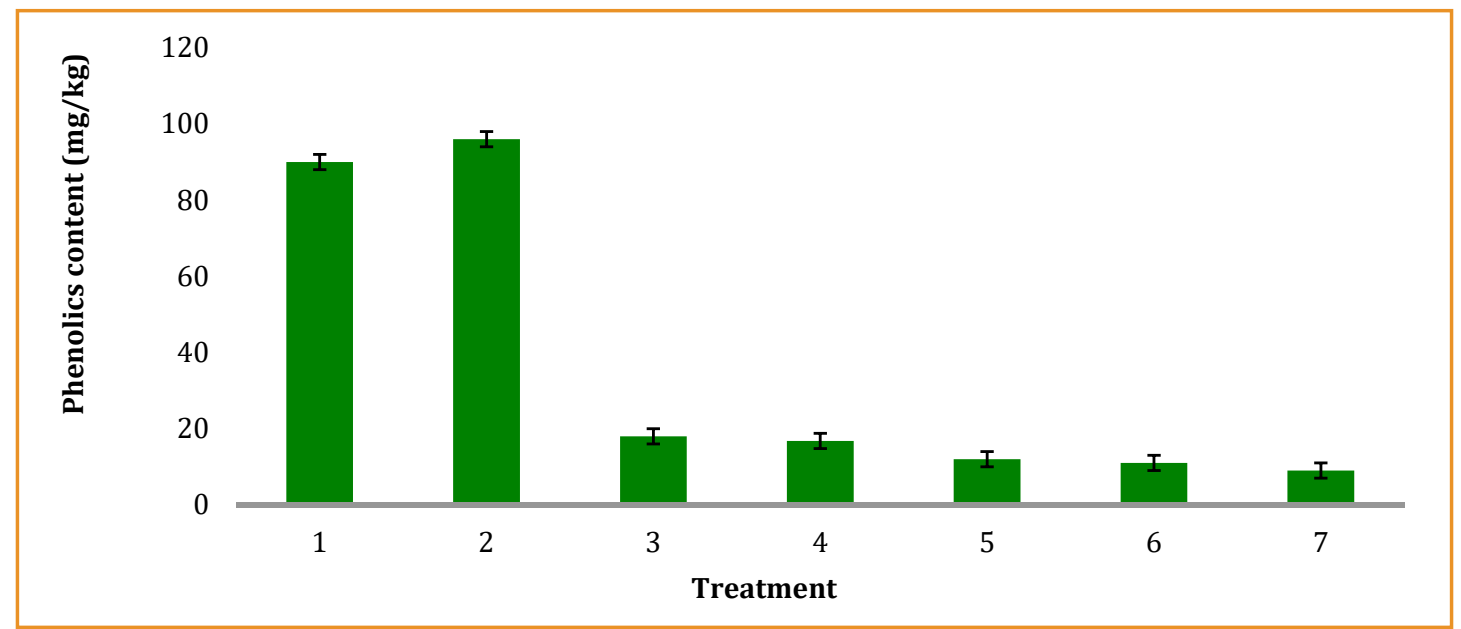

Figure 4 Effect of cover crops cultivation on the content of free phenolics in the soil from-under 30-yearold peach trees after 126 days of cultivation of cover crops

1 - control; 2 - Galega orientalis; 3 - Calendula officinalis; 4 - Fagopyrum tataricum; 5 - Sinapis alba; 6 Phacelia tanacetifolia; 7 - Melissa officinalis. Vertical bars - the least significant difference at $p<0.01$

Soil quality is one of the central factors that control yield and crop health in agro-ecosystems. Amelioration of soil allelopathic and biochemical regimes control its microbocenoses, organic matter dynamics, nutrient mineralization and suppression of pathogens. Today cover crops are widely used for increasing crop health in sustainable and organic agriculture (Moroz, 1990; Manici et al., 2015; Morugán-Coronado et al., 2020). Primary benefits from cover crops conventionally include improving soil quality (soil macroporosity, water retention, nutrient supply, etc.), erosion (Bacq-Labreuil et al., 2019) and weed control (Didyk and Mashkovska, 2006; Manici et al., 2015). The results of our study demonstrated the effectiveness of cover cropping in the alleviation of soil sickness caused by the accumulation of phytotoxic allelochemicals.

\section{Conclusions}

The data obtained indicate that SS in the investigated 30-year-old plantations of apple and peach trees are associated with the accumulation of toxic concentrations of phenolic allelochemicals, as well as toxic metals of $\mathrm{Mn}$ and Fe. Cultivation of cover crops improved the allelopathic and biochemical regime of the SS. In particular, it significantly reduced the concentrations of phytotoxic phenolics and improved the biological activity of soil. The 
highest ameliorative effect was observed after the cultivation of Tagetes tenuifolia, Phacelia tanacetifolia, and Sinapis alba. We consider these cover crops to be promising as eco-friendly solutions to alleviate SS in the apple tree and peach tree plantations.

\section{References}

BACQ-LABREUIL, A., CRAWFORD, J., MOONEY, S.J., NEAL, A.L., RITZ, K. 2019. Phacelia (Phacelia tanacetifolia Benth.) affects soil structure differently depending on soil texture. In Plant Soil., vol. 441. p. 543-554. https://doi.org/10.1007/s11104-019-04144-4

BENIZRI, E., PIUTTI, S., VERGER, S., PAGÈS, L., VERCAMBRE, G., POESSEL, J.L., MICHELOT, P. 2005. Replant diseases : Bacterial community structure and diversity in peach rhizosphere as determined by metabolic and genetic fingerprinting. In Soil Biol. and Biochem., vol. 37. p. 1738-1746. https://doi. org/10.1016/j.soilbio.2005.02.009

BITYUTSKIY, N. 2015. Mineral nutrition of plants. St. Petersburg: St. Petersburg. Univ. 540 p.

BRENNAN, E., SMITH, R. 2018. Mustard Cover Crop Growth and Weed Suppression in Organic, Strawberry Furrows in California. In HortScience, vol. 53 (4), p. 432-440. https://dx.doi.org/10.21273/ HORTSCI12576-17

ČATSKÁ, V. VANČURA V., HUDSKÁ, G., PŘIKRYL Z. 1982. Rhizosphere micro-organisms in relation to the apple replant problem. In Plant and Soil, vol. 69(2), p. 187-197. https://doi.org/10.1007/ BF02374514

CESARANO, G., ZOTTI, M., ANTIGNANI, V., MARRA, R., SCALA, F., BONANOMI, G. 2017. Soil sickness and negative plant-soil feedback: A reappraisal of hypotheses. In Journal of Plant Pathology, vol. 99. p. 545-570. http://dx.doi.org/10.4454/jpp.v99i3.3960

DIDYK, N.P., MASHKOVSKA, S.P. 2007. Evaluation of weed suppressive effect of allelochemicals of ornamental marigold species. In Allelopathy: New Concepts and Methodology. Enfield, NH, USA : Science Publishers, Inc., p. 239-250. ISBN 978-1-57808-446-3.

GRODZINSKI, A.M., GOROBETS, S.A., KRUPA, L.I. 1988. Guide to the application of biochemical methods in allelopathic soil studies. Kyiv: CRBS. 18 p.

GRODZINSKIY, A.M. 1991. Plant allelopathy and soil sickness: Selected works. Kyiv: Naukova Dumka. 432 p. ISBN 5-12-001928-5 (Russian)

HOSSAIN, S., BERGKVIST, G., GLINWOOD, R., BERGLUND, K., MÅRTENSSON, A., HALLIN, S., PERSSON P. 2015. Brassicaceae cover crops reduce Aphanomyces pea root rot without suppressing genetic potential of microbial nitrogen cycling. In Plant Soil, vol. 392, p. 227-238. https://doi. org/10.1007/s11104-015-2456-y

KIMPINSKI, J., ARSENAULT, W.J., GALLANT, C. E., SANDERSON J. B. 2000. The effect of marigolds (Tagetes spp.) and other cover crops on Pratylenchus penetrans and on following potato crops. In Supplement to the Journal of Nematology, 32 (4S), p. 531-536.

LIU, Z., WANG, X., MA, H., QI, Y. 2008. Analysis of allelochemicals in extracts from peach and their effects on growth of Amygdalus persica seedlings. In Acta Hort. (ISHS), vol. 774(13), p. 113-120. https:// doi.org/10.17660/ActaHortic.2008.774.13

LÜ, LI-HUI, WU, QIANG-SHENG. 2018. Mitigation of replant disease by mycorrhization in horticultural plants: A review. In Folia Horticulturae, vol. 30(2), p. 269-280. https://doi.org/10.2478/ fhort-2018-0022

MAKOI, J.H.J.R., NDAKIDEMI, P.A. 2007. Biological, ecological and agronomic significance of plant phenolic compounds in rhizosphere of the symbiotic legumes. In African Journal of Biotechnology, vol. 6(12), p.1358-1368.

MANICI, L.M., CIAVATTA, C., KELDERER, M., ERSCHBAUMER, G. 2003. Replant problems in South Tyrol: role of fungal pathogens and microbial population in conventional and organic apple orchards. In Plant and Soil. vol. 256 (2). p. 315-324. https://doi.org/10.1023/A:102610300 
MANICI, L.M., KELDERER, M., CAPUTO, F., NICOLETTI, F., DE LUCA PICIONE, F., TOPP, A.R. 2015. Impact of cover crop in pre-plant of apple orchards: relationship between crop health, root inhabiting fungi and rhizospheric bacteria. In Can. J. Plant Sci., vol. 5, p. 947-958. https://doi.org/10.1139/ CJPS-2015-013

MATTHIESSEN, J.N., KIRKEGAARD, J.A. 2006. Biofumigation and enhanced biodegradation: Opportunity and challenge in soilborne pest and disease management. In Critical Reviews in Plant Sciences, vol. 25, p. 235-265.

MOROZ, P.A. 1990. Allelopathy in fruit gardens. Kyiv: Naukova dumka, 208 p. ISBN 5-12-000820-8 : 3.10 p.

MORUGÁN-CORONADO, A., LINARES, C., GÓMEZ-LÓPEZ, M., FAZ, A., ZORNOZA, R. 2020. The impact of intercropping, tillage and fertilizer type on soil and crop yield in fruit orchards under Mediterranean conditions: A meta-analysis of field studies. In Agricultural Systems, vol. 178, p. 102736. https://doi.org/10.1016/j.agsy.2019.102736

PATKOWSKA, E., KONOPIŃSKI M. 2011. Cover crops and soil-borne fungi dangerous towards the cultivation of salsify (Tragopogon porrifolius var. sativus (Gaterau) Br.). In Acta Scientiarum Polonorum, Hortorum Cultus, vol. 10, p. 167-181.

PERVEEN, S., YOUSAF, M., MUSHTAQ M., SARWAR, N., YAHYA, K. M., NADEEM, S. (2019). Bioherbicidal potential of some allelopathic agroforestry and fruit plant species against Lepidium sativum. In Soil and Environment, vol. 38 (1), p. 119-126. https://doi.org/10.25252/SE/19/71655

POLITYCKA, B., ADAMSKA, D. 2003. Release of phenolic compounds from apple residues decomposing in soil and the influence of temperature on their degradation. In Polish Journal of Environmental Studies, vol. 12(1), p. 95-98.

REIGOSA, M. J., PAZOS-MALVIDO, E. 2007. Phytotoxic effects of 21 plant secondary metabolites on arabidopsis thaliana germination and root growth. In J Chem Ecol., vol. 33. p. 1456-1466. https:// doi.org/10.1007/s10886-007-9318-x

RINIKIS, G. YA., NOLLENDORF, V.F. 1982. Balanced nutriotion of plants with macro- and micronutrients. Riga: Znaniye, $202 \mathrm{p}$.

RODRIGUES, M.Â., DIMANDE, P., PEREIRA, E.L., FERREIRA, I.Q., FREITAS, S., CORREIA, C.M., MOUTINHOPEREIRA, J., ARROBAS, M. 2015. Early-maturing annual legumes: an option for cover cropping in rainfed olive orchard. In Nutr Cycl Agroecosyst., vol. 103(2), p. 153-166. https://doi.org/10.1007/ $\underline{\text { s10705-015-9730-5 }}$

SÁNCHEZ, E. E., GIAYETTO, A., CICHÓN, L., FERNÁNDEZ, D., ARUANI, M. C., CURETTI, M. 2007. Cover crops influence soil properties and tree performance in an organic apple (Malus domestica Borkh) orchard in northern Patagonia. In Plant and Soil, vol. 292(1-2), p. 193-203. https://doi. org/10.1007/s11104-007-9215-7

SINGH, D.R., SHARMA, D., KAUSHAL, R. 2017. Controlling replant disease of apple in Himachal Pradesh, India by rootstocks and soil agro-techniques. In The Pharma Innovation Journal, vol. 288, p. 288293. www.thepharmajournal.com

THAKUR, K., SHARMA, D., PRASAD, H. 2018. Efficacy of different soil agro-techniques against peach replant disease as determined by vegetative growth of the plants under surveillance in a replanting site. In International Journal of Chemical Studies, vol. 6(2). p. 3143-3146.

YIN, C., XIANG, L., WANG, G., WANG, Y., SHEN, X., CHEN, X., et al. 2016. How to plant apple trees th reduce replant disease in apple orchard: a study on the phenolic acid of the replanted apple orchard. In PLoS ONE, vol. 11(12). e0167347. https://doi.org/10.1371/journal.pone.0167347

ZHOU, T., JIAO, K., QIN, S., LYU, D. 2019. The impact of cover crop shoot decomposition on soil microorganisms in an apple orchard in northeast China. In Saudi Journal of Biological Sciences, vol. 26 (8), p. 1936-1942. https://doi.org/10.1016/j.sjbs.2019.07.004 